\title{
Pengaruh Permainan dalam Pembelajaran Fisika Terhadap Motivasi Belajar Peserta Didik
}

\author{
Arif Rahman Aththibby, Dedi Hidayatullah Alarifin \\ Program Studi Pendidikan Fisika Universitas Muhammadiyah Metro \\ J1. Ki Hajar Dewantara Kel. Iring Mulyo, Kota Metro, Lampung \\ Surat-e: aththibby@yahoo.com
}

\begin{abstract}
Menanamkan rasa suka, senang, tertarik, dan butuh kepada peserta didik merupakan salah satu kiat yang efektif untuk keberhasilan belajar peserta didik. Belajar tadak hanya dibatasi pada satu tempat, kondisi, ruang, dan waktu tertentu saja. Siswa akan termotivasi mengikuti pembelajaran dengan baik jika guru mampu menciptakan suasana pembelajaran yang menarik dan menyenangkan bagi siswa. Keaktifan belajar merupakan hal yang sangat penting dalam pembelajaran untuk mempermudah siswa dalam mencapai tujuan pembelajaran yang telah ditetapkan guru sehingga pada akhirnya prestasi belajar siswa pun dapat ditingkatkan. Untuk meningkatkan minat dan aktivitas belajar dalam pembelajaran fisika diperlukan suasana yang menyenangkan. Hal itu dapat dilakukan melalui kombinasi brain Gym, ice breaking, dan penggunaan alat peraga dalam proses pembelajaran fisika. Hasil dari penelitian yang dilakukan tentang pengaruh permainan dalam pembejaran fisika terhadap motivasi belajar peserta didik dapat disimpulkan bahwa implementasi permainan dalam pembelajaran fisika baik dan layak untuk digunakan dalam proses pembelajaran. Hal ini terlihat dari hasil rata-rata motivasi belajar siswa dan juga hasil uji-t yang dilakukan. Oleh karena itu, sebagai upaya meningkatkan motivasi belajar fisika bagi peserta didik, guru memiliki opsi menggunakan permainan dalam pembelajaran.
\end{abstract}

Kata kunci: Motivasi, Permainan, Brain Gym, Ice Breaking.

\section{Pendahuluan}

Guru seharusnya mampu mengubah suasana kelas atau pelajaran yang kaku menjadi lebih menyenangkan. Dengan menawarkan susana yang lebih ringan dan menyenagkan dirasa akan meberikan efek yang postif pada peserta didik. Jika peserta didik merasa nyaman dalam kondisi pembelajaran maka dapat dipastikan siswa tersebut akan berhasil dengan baik dalam memahami ilmu yang didalaminya. Banyak tawaran yang bisa disajikan oleh seorang pendidik dalam melakaukan pembelajaran agar lebih menyenagkan. Salah satu yang dapat ditawarkan oleh seorang guru adalah adanya permainan dalam pembelajaran.

Menanamkan rasa suka, senang, tertarik, dan butuh kepada peserta didik merupakan salah satu kiat yang efektif untuk keberhasilan belajar peserta didik. Belajar tadak hanya dibatasi pada satu tempat, kondisi, ruang, dan waktu tertentu saja.
Games atau permainan saat ini juga menjadi alternatif yang sering digunakan oleh para presenter, guru, dosen, pelatih dan pembicara untuk memecah kebekuan dan membuat suasana pembelajaran menjadi menyenangkan.

Siswa akan termotivasi mengikuti pembelajaran dengan baik jika guru mampu menciptakan suasana pembelajaran yang menarik dan menyenangkan bagi siswa. Keaktifan belajar merupakan hal yang sangat penting dalam pembelajaran untuk mempermudah siswa dalam mencapai tujuan pembelajaran yang telah ditetapkan guru sehingga pada akhirnya prestasi belajar siswa pun dapat ditingkatkan.

Untuk meningkatkan minat dan aktivitas belajar dalam pembelajaran fisika diperlukan suasana yang menyenangkan. Hal itu dapat dilakukan melalui kombinasi brain Gym, ice breaking, dan penggunaan alat peraga dalam proses pembelajaran fisika.

Untuk mengoptimalkan kemampuan otak kita, kita gunakan metode brain gym (senam otak) yang dimana dapat meningkat fungsi otak kanan dan otak kiri dan juga dapat penyeimbang antara otak kanan dan otak kiri. 
Pengoptimalkan otak kita dapat membuat kita mempunyai daya ingat yang tajam.

Selama ini banyak Siswa menganggap bahwa fisika merupakan pelajaran yang sulit dan menakutkan. Selain itu motivasi siswa dalam pembelajaran fisika dalam hal perasaan senang, kemauan dan kesadaran masih rendah. Ditambah kurangnya konsentrasi siswa dalam hal perhatian dan sikap siswa saat pelajaran berlangsung, sehingga kondisi pembelajaran di kelas kurang kondusif. Oleh karena itu diperlukan sutu suasana dan kondisi yang menyenangkan dalam pembelajaran fisika.

Penerapan permainan dalam pembelajaran. Baik penggunaan brain gym yang bermanfaat dalam optimalisasi kerja otak maupun ice breaking guna menghidupkan suasana pembelajaran.

\section{Kajian Pustaka}

\section{Permainan dalam Pembelajaran Fisika}

Permainan (play) adalah suatu kegiatan yang menyenangkan yang dilaksanakan untuk kepentingan kegiatan itu sendiri [I]. Permainan menurut Johan Huizinga [2] adalah "suatu perbuatan atau kegiatan sukarela, yang dilakukan dalam batas-batas ruang dan waktu tertentu yang sudah ditetapkan, menurut aturan yang sudah diterima secara sukarela tapi mengikat sepenuhnya, dengan tujuan dalam dirinya sendiri, disertai oleh perasaan tegang dan gembira, dan kesadaran lain daripada kehidupan seharihari”. Berdasarkan definisi tersebut dapat disimpulkan bahwa permainan memiliki ciri khas, batasan, dan aturan yang mengikat yang membedakannya dengan kegiatan dalam kehidupan yang lain.

\section{Pembelajaran Fisika}

Fisika merupakan mata pelajaran yang terkesan kaku dan membosankan bagi siswa. Hal ini mengakibatkan rendahnya kualitas proses dan prestasi belajar. Hal ini sejalan dengan penelitian pada pustaka [3] yang menunjukkan oleh fakta dalam pembelajaran fisika motivasi belajar siswa rendah dan siswa mengalami kesulitan belajar pada mata pelajaran fisika. Oleh karena itu perlu adanya stimulus berupa permainan dalam pembelajaran fisika guna meningkatkan motivasi belajar siswa.

Pembelajaran fisika baik di sekolah maupun di perguruan tinggi tekanan intinya pada upaya memahami konsep fisika melalui proses internalisasi dalam diri peserta didik dan selanjutnya penguasaan konsep tersebut diterapkan untuk memecahkan masalah yang dihadapinya $[4]$.

\section{Permainan dalam Pembelajaran Fisika}

Permainan dalam pembelajaran fisika diperlukan untuk menjaga konsentrasi siswa. Selain itu dengan adanya permainan dalam pembelajaran fisika diharapkan pembelajaran fisika yang selama ini terkesan kaku menjadi lebih hdup dan aktif. Beberapa manfaat yang bisa diperoleh seorang siswa melalui permainan antara lain [5]:

I. Aspek fisik, 2. Aspek perkembangan motor kasar dan halus, 3. Aspek sosial, 4. Aspek bahasa, 5. Aspek emosi dan kepribadian, 6. Aspek kognisi. 7. Aspek ketajaman panca indra, 8. Aspek perkembangan kreativitas, 9. Terapi.

Aspek yang terdapat dari sisi permainan dalam pembelajaran fisika antara lain aspek fisik, aspek sosial, aspek bahasa, aspek emosi dan kepribadian, aspek kognisi, aspek perkembangan kreativitas.

\section{Brain Gym}

Pustaka[6] juga menyatakan bahwa keuntungan dan manfaat dari senam otak antara lain adalah: I) anak dapat belajar dengan nyaman tanpa stress, 2) waktu yang dibutuhkan untuk senam otak cukup singkat sehingga tidak mengganggu proses belajar, 3) praktik senam otak dapat dilakukan di mana saja dan kapan saja tanpa membutuhkan tempat dan bahan yang khusus, 4) senam otak dapat digunakan untuk membantu semua situasi, baik dalam belajar maupun dalam kehidupan sehari-hari, 5) senam otak pada gilirannya dapat meningkatkan kepercayaan diri anak, 6) senam otak segera menunjukkan hasil dan sangat efektif untuk menangani anak yang mengalami hambatan dalam belajar atau stres belajar, 7) senam otak diakui sebagai salah satu teknik belajar terbaik versi "National Learning Foundation USA" dan praktik senam otak telah menyebar ke seluruh dunia.

Menurut Jumraini Tammase dalam[7], senam otak atau brain gym dapat meningkatkan Kemampuan berbahasa, daya ingat dan konsentrasi belajar.

Brain Gym adalah teknik yang dikembangkan oleh Dr Paul Dennison yang menyarankan penggunaan gerakan tubuh dalam pembelajaran. Dennison menunjukkan bahwa 25 gerakan fisik memiliki efek positif yang signifikan untuk sejumlah besar siswa ketika belajar [8].

\section{Ice Breaking}

Ice breaking adalah istilah untuk menjelaskan mengenai suatu proses yang perlu dilakukan fasilitator untuk 
mengubah state of mind peserta. Kegiatan ini biasanya berupa suatu kelucuan, kadang memalukan, kadang hanya sekedar informasi dan ada kalanya pencerahan. Jika memakai kegiatan yang sesuai dengan kondisi di peserta, ice breaking bisa menjadi alat yang tepat untuk memfasilitasi kesuksesan sebuah acara termasuk dalam proses pembelajaran.

Karakteristik teknik Icebreaker adalah menciptakan suasana belajar yang menyenangkan. Salah satu caranya dengan meramu Icebreaker yang disisipkan dalam proses pembelajaran, yang dapat dilakukan dengan menyajikan lelucon, variasi tepuk tangan, yel-yel, bernyanyi, permainan (games) dan sebagainya pada saat membuka pelajaran, jeda pada saat pertengahan penyampaian materi pembelajaran dan pada kegiatan menutup pembelajaran.

Icebreaker jenis games dapat membuat konsentrasi siswa terfokus didalam kelas sehingga materi pelajaran akan lebih mudah dicerna karena Icebreaker jenis games merupakan kegiatan yang paling disukai oleh peserta didik [9].

\section{Motivasi}

Motivasi adalah suatu keadaan internal yang membangkitkan kita untuk bertindak, mendorong kita ke arah tertentu, dan membuat kita terlibat dalam kegiatan tertentu [IO]. Pustaka [II] menyatakan bahwa seseorang yang memiliki motivasi besar akan menampakkan minat, perhatian, konsentrasi penuh, ketekuanan tinggi, serta berorientasi pada prestasi tanpa mengenal perasaan bosan, jenuh, dan menyerah. Dengan demikian, motivasi dapat diartikan sebagai keadaan internal dari seseorang yang mencerminkan minat, perhatian, serta penuh konsentrasi guna mencapai prestasi.

Peserta didik dengan motivasi belajar yang baik memiliki hasil belajar yang akan lebih baik. Dalam proses belajar, motivasi seseorang tercermin melalui ketekunan yang tidak mudah patah untuk mencapai sukses, meskipun dihadang banyak kesulitan.

\section{Metode Penelitian/Eksperimen}

\section{Metode Penelitian}

Metode yang digunakan dalam penelitian ini adalah penelitian eksperimen (experimental research). Penelitian eksperimen ini dilakukan dengan memilih desain Quasi eksperimen. pada desain ini kelompok eksperimen maupun kelompok kontrol dipilih secara random. Dalam desain ini, kelompok eksperimen diberikan perlakuan berupa permainan dalam pembelajaran fisika sedangkan kelompok kontrol tidak diberikan perlakuan berupa pemberian permainan dalam pembelajaran fisika.

\section{Teknik Pengumpulan Data}

Penelitian ini menggunakan data primer yang dikumpulkan melalui survei dengan instrumen penelitian berbentuk angket. Pengukuran dilakukan pada situasi nyata yang dilihat menurut penilaian responden tentang apa yang dialami, bukan apa yang diinginkan. Instrumen pengumpulan data, disusun dalam bentuk skala sikap metode likert. Angket yang digunakan berfungsi sebagai alat mengetahui implementasi permainan dalam pembelajaran fisika terhadap kesan yang ditimbulkan. Angket yang diberikan kepada siswa adalah angket motivasi belajar peserta didik.

Data yang didapatkan kemudian diolah dan diuji tingkat pengaruh antara penerapan permainan dalam pembelajaran fisika terhadap motivasi belajar siswa menggunakan perangkat lunak SPSS.

\section{Hasil Penelitian dan Pembahasan}

Perbandingan hasil implementasi permainan dalam pembelajaran fisika terhadap motivasi belajar peserta didik dapat terlihat pada tabel I.

Tabel I. Perbandingan hasil implementasi permainan dalam pembelajaran fisika terhadap motivasi belajar

\begin{tabular}{lrrlrr}
\hline \multicolumn{3}{c}{ Kelompok Eksperimen } & \multicolumn{3}{c}{ Kelompok Kontrol } \\
\hline No. & $\begin{array}{c}\text { Nilai } \\
\text { Rata-rata }\end{array}$ & $\begin{array}{c}\text { Persentase } \\
\text { Motivasi }\end{array}$ & No. & $\begin{array}{r}\text { Nilai } \\
\text { Rata-rata }\end{array}$ & $\begin{array}{l}\text { Persentase } \\
\text { Motivasi }\end{array}$ \\
\hline I & 3.3 & 82.5 & I & 2.9 & 72.5 \\
2 & 3.4 & 85 & 2 & 2.7 & 67.5 \\
3 & 3.1 & 77.5 & 3 & 2.8 & 70 \\
4 & 3.2 & 80 & 4 & 3.1 & 77.5 \\
5 & 3.4 & 85 & 5 & 2.7 & 67.5 \\
6 & 3.3 & 82.5 & 6 & 3 & 75 \\
7 & 3.1 & 77.5 & 7 & 2.5 & 62.5 \\
8 & 3.2 & 80 & 8 & 2.9 & 72.5 \\
9 & 3.2 & 80 & 9 & 2.8 & 70 \\
I0 & 3.2 & 80 & 10 & 2.4 & 60 \\
II & 3.1 & 77.5 & II & 2.7 & 67.5 \\
I2 & 3.1 & 77.5 & I2 & 2.8 & 70 \\
I3 & 2.9 & 72.5 & I3 & 3 & 75
\end{tabular}




\begin{tabular}{rrrrrr}
\hline \multicolumn{2}{c}{ Kelompok Eksperimen } & \multicolumn{3}{c}{ Kelompok Kontrol } \\
\hline No. & $\begin{array}{c}\text { Nilai } \\
\text { Rata-rata }\end{array}$ & $\begin{array}{c}\text { Persentase } \\
\text { Motivasi }\end{array}$ & No. & $\begin{array}{c}\text { Nilai } \\
\text { Rata-rata }\end{array}$ & $\begin{array}{l}\text { Persentase } \\
\text { Motivasi }\end{array}$ \\
\hline I4 & 3.3 & 82.5 & I4 & 2.5 & 62.5 \\
I5 & 3 & 75 & I5 & 2.7 & 67.5 \\
I6 & 3.3 & 82.5 & I6 & 2.4 & 60 \\
I7 & 2.9 & 72.5 & I7 & 2.1 & 52.5 \\
I8 & 3.3 & 82.5 & I8 & 2.9 & 72.5 \\
I9 & 3.1 & 77.5 & I9 & 2.9 & 72.5 \\
20 & 3.2 & 80 & 20 & 2.9 & 72.5 \\
& 3.18 & 79.5 & & 2.74 & 68.375 \\
\hline
\end{tabular}

Uji normalitas diperlukan untuk mengetahui apakah data berasal dari populasi yang terdistribusi normal atau tidak, sedangkan uji homogenitas diperlukan untuk mengetahui apakah data berasal dari sampel yang homogen atau tidak.

Tabel 2. Hasil Uji Normalitas

\begin{tabular}{llc}
\hline \multirow{2}{*}{$\mathrm{N}$} & \multicolumn{2}{r}{ Motivasi } \\
\hline Normal Parameters $^{\mathrm{a}}$ & & 40 \\
\cline { 2 - 3 } & $\begin{array}{c}\text { Mean } \\
\text { Deviation }\end{array}$ & 29.5750 \\
\hline Most Extreme Differences & Absolute & .132 \\
\cline { 2 - 3 } & Positive & .078 \\
\cline { 2 - 3 } & Negative & -.132 \\
\hline Kolmogorov-Smirnov Z & & .834 \\
\hline Asymp. Sig. (2-tailed) & & .489 \\
\hline
\end{tabular}

Tabel 3. Hasil Uji Homogenitas

\begin{tabular}{lllll}
\hline & Levene Statistic & dfI & df2 & Sig. \\
\hline Motivasi & 4.046 & I & 38 & $.05 \mathrm{I}$ \\
\hline
\end{tabular}

Berdasarkan uji normalitas dan homogenitas, didapatkan hasil seperti pada tabel 2 dan 3. Kesimpulan dari hasil tabel tersebut adalah data yang diuji terbukti normal dan homogen. Hal itu berarti dada didapatkan dari populasi yang terdistribusi normal dan sampel yang dipilih adalah sample yang homogen.

Tahap Selanjutnya adalah menguji pengaruh implementasi permainan dalam pembelajaran fisika terhadap motivasi belajar peserta didik. Berdasrkan hasil uji menggunakan perangkat lunak SPSS 16, didapatkan hasil seperti pada tabel 4 .

Berdasarkan anlisis data didaptkan hasil bahwa permainan dalam pembelajaran fisika memiliki pengaruh positif terhadap motivasi belajar siswa. Dengan nilai rata-rata motivasi belajar yang lebih baik dan uji lanjut yang juga menghasilkan nilai pengaruh yang signifikan, maka dapat dinyatakan bahwa implementasi permainan dalam pembelajaran fisika baik untuk menjadi terobosan bagi pengajar fisika dalam upaya meningkatkan hasil belajar peserta didik.

\section{Kesimpulan}

Berdasarkan hasil penelitian tentang pengaruh permainan dalam pembejaran fisika terhadap motivasi belajar peserta didik dapat disimpulkan bahwa implementasi permainan dalam pembelajaran fisika baik dan layak untuk digunakan dalam proses pembelajaran. Hal ini terlihat dari hasil ratarata motivasi belajar siswa dan juga hasil uji-t yang dilakukan. Oleh karena itu, sebagai upaya meningkatkan motivasi belajar fisika bagi peserta didik, guru memiliki opsi menggunakan permainan dalam pembelajaran.

\section{Kepustakaan}

[I] Murtiningsih. "Video Games dan Filsafat Pendidikan: Pendekatan Teori Simulacra Jean Baudrillad". Prosiding the 4th international conference on indonesian studies: "Unity, Diversity, and Future", Lhoksumawe. 2013.

[2] Triwiyono, Program Pembelajaran Fisika Menggunakan Metode Eksperimen Terbimbing Untuk Meningkatkan Keterampilan Berpikir Kritis. Jurnal Pendidikan Fisika Indonesia, Vol. 7, 201 I, pp: 80-83.

[3] Suparwoto, "Simetri Dalam Fisika dan Implementasinya dalam Pendidikan Karakter". Prosiding Seminar Nasional Penelitian, Pendidikan dan Penerapan MIPA, Fakultas MIPA, Universitas Negeri Yogyakarta. $201 \mathrm{I}$.

[4] Pivec, Game-based Learning or Game-based Teaching. Becta, 2009.

[5] Zaviera, F. Mengenali \& Memahami Tumbuh Kembang Anak, Katahati. Yogyakarta.2008.

[6] Gunadi, Meningkatkan Kecerdasan Anak. Jakarta: Penebar Swadaya, 2009.

[7] Puspananda, Eksperimentasi Model Pembelajaran Kooperatif Tipe Stad Dipadukan dengan Senam Otak Terhadap Prestasi Belajar Matematika. Magistra No. 89 Th. XXVI 20I4.pp:I8-24

[8] Sunarto, Icebreaker dalam Pembelajaran Aktif, Cakrawala Media. Surakarta, 2012.

[9] Rusmawan, Faktor Yang Memengaruhi Kesulitan Belajar IPS Siswa Sekolah Dasar, Cakrawala Pendidikan, 2013, Th. XXXII, No. 2. , pp. 285-295.

[10] Arigiyati, Tri Astuti., Pengaruh Kedisiplinan, Motivasi Belajar, dan Dukungan Orang tua terhadap Prestasi Belajar Mata Kulian Metode Statistika Mahasiswa Program Studi Pendidikan Matematika Angkatan 2009. Jurnal Wacana Akademika, Volume 3 No.9, 20II. pp. 922-93. 